\title{
Factors shaping the economic landscape in today's world
}

\author{
Andrés Rodríguez-Pose ${ }^{1}$
}

Published online: 28 February 2017

(C) The Japan Section of the Regional Science Association International 2017

It is with real pleasure that I welcome the birth of the Asia-Pacific Journal of Regional Science. The publication of this first issue could not be more timely. Recent events, such as Brexit and President Trump's election, have made plainly clear how important it is to understand the factors behind the location of economic activity and behind changes in territorial inequality in our current world. When economic activity is unevenly distributed, when some places accumulate investment, production, and wealth, while others lag behind, and when processes of trade and economic integration benefit some cities and regions often at the expense of others, the whole base on which modern, open economies are founded is called into question and the pillars on which the economic system rest are shaken.

No place in the world epitomizes this more than the Asia-Pacific region. In this part of the globe, rapid economic growth-at levels which make the so-called developed economies blush — has been coupled with a conspicuous rise in withincountry inequality. Globalization, rapid industrialization, and regional integration have transformed the once lagging-behind Asia-Pacific economies into production and, increasingly, innovation powerhouses, making the region the envy of the world. However, swift development is coming at a price, as many cities and regions struggle with the rapid pace of change, with the need to restructure their economies, and with the necessity to compete with far flung places often more capable to furnish the world market with better products at lower prices. Growth and dynamism, on the one hand, and decay and inequality, on the other, offer both reasons for optimism in the future, but also are a warning about the risks looming ahead.

There is, therefore, a greater need than ever to understand what factors determine the location of economic activity in a world in constant change and where trade and

Andrés Rodríguez-Pose

A.Rodriguez-Pose@1se.ac.uk

1 The London School of Economics and Political Science, London, UK 
economic integration are likely to ebb and flow even more than before. The AsiaPacific Journal of Regional Science represents the ideal platform for displaying this knowledge and the policy solutions emanating from it. The blend of innovative theoretical studies and solid empirical analysis at the heart of the journal, alongside its focus on one of the most dynamic parts of the world will certainly make it a magnet not only for those scholars the world over attracted to the region, but also for those that have the responsibility of finding solutions to the current territorial challenges.

Good luck to the editorial team in this fascinating journey and long live the AsiaPacific Journal of Regional Science! 